\title{
ECONOMIC EMPOWERMENT OF POOR FAMILY HEADS THROUGH MARKET-BASED MICRO BUSINESS GROUPS IN MKS DISTRICT, BUKITTINGGI CITY
}

\section{Reflinda}

Fakutlas Tarbiyah dan Imu Keguruan, LAIN Bukittinggi, reflinda9@gmail.com

\author{
Diterima: 24 Januari 2019 \\ Direvisi :15 Mei 2019 \\ Diterbitkan: 30 Juni 2019
}

\begin{abstract}
Mandiangin Koto Selayang is one of the three sub-districts in Bukittinggi City. In this sub-district, there are 116 poor female family head (PEKKA) found and it is a sub-district that has a lot of poor PEKKA compared to the two other sub-districts in Bukittiggi City. The target of this service is conducting an empowerment program to overcome the economic problems of poor PEKKA. The empowerment did to overcome economic challenges and to form market-based microbusiness groups. In which PEKKA is grouped based on the types of businesses owened and doing engagement the interest of increasing the economic efforts of the groups. The types of micro-group businesses carried out are, making accessories, snacks and daily selling businesses. The engagement is belping the businesses, encourage doing business, helping the marketing. The results of the assistance show that PEKKA needs cement to support and it needs capital in developing business groups.
\end{abstract}

Keywords: Empowerment, Woman, Poor Family Heads

\begin{abstract}
Abstrak
Mandiangin Koto Selayang merupakan salah satu dari tiga kecamatan yang berada di Kota Bukittinggi, di kecamatan ini ditemukan PEKKA miskin sebanyak $116 \mathrm{KK}$ dan merupakan kecamatan yang laing banyak PEKKA miskin dibandingkan dengan dua kecamatan lainnya di Kota Bukittiggi. Sasaran dari pengabdian ini merupakan kelompok dari PEKKA miskin tersebut dengan melakukan program pemberdayaan untuk mengatasi masalah ekonomi yang dihadapinya. Pemberdayaan yang dilakukan untuk mengatasi permasalahan ekonominya adalah dengan membentuk kelompok usaha mikro berbasis pasar. Dimana PEKKA di kelompokan berdasarkan jenis-jenis usaha yang dilakukannya dan mendampinginya supaya bisa menguasai pasar untuk kepentingan kemajuan usaha-usaha ekonomi kelompok yang lakukan itu. Diantara jenis usaha kelompok mikro yang dilakukan adalah, membuat asesoris, makanan ringan dan usaha jualan harian. Diantara program pendampingan untuk kepentingan kemajuan usaha itu adalah telah dilakukan terhadap PEKKA ini dampingan komunkasi usaha, motivasi untuk berusaha, membantu informasi pemasaran. Hasil dari pendampingan menunjukkan bahwa, PEKKA mempunyai semenagat untuk berusaha, dan sangat membutuhkan modal dalam pengembangan usaha kelompok yang dilakukannya.
\end{abstract}

Kata Kunci: Pemberdayaan, Perempuan, Kepala Keluarga Miskin.

\section{Latar Belakang}

Bukittinggi merupakan kota terbesar kedua di Sumatera Barat setelah kota Padang. Dengan jumlah penduduk saat sekarang 25.446 jiwa, dimana 13.483 jiwa adalah perempuan dan 11.963 laki-laki, dengan jumlah
KK 27.689. Kota ini terdiri dari tiga kecamatan yakni kecamatan Aur Birugo Tigo Baleh (ABTB), Guguk Panjang (GP) dan Mandiangin 
Koto Selayang (MKS). Sebagai sebuah kota, maka sosial ekonomi masyarakatnya beragam. ${ }^{1}$

Namun dilihat dari kondisi ekonomi keluarga, ditemukan jumlah Kepala Keluarga yang hidup digaris kemiskinan sebanyak 3657 KK.. Menurut data Kantor Pemberdayaan Perempuan dan Anak Kota Bukittinggi, tahun 103 dari diantara KK miskin ini terdapat 282 KK merupakan Perempuan Kepala Keluarga (PEKKA) miskin. Dari tiga kecamatan itu, dimana $83 \mathrm{KK}$ PEKKA miskin berada di kecamatan ABTB dan 83 lagi di kecamatan GP, sedangkan di kecamatan MKS terdapat jumlah PEKKA miskin 116 dan semuanya beragama Islam (KPP dan KB, 2017). Oleh sebab itu diambil pengabdian ini di kecamatan MKS, karena sebanyak 25 orang PEKKA di MKS itu sudah mendapatkan pemberdayaan dan sudah membentuk kelompok unit usaha mikro dengan memproduksi asesoris dalam berbentuk dan variasi dengan adanya pemberdayaan tahap pertama yang dibiayai melalui kompetitif diktis tahun 2014 . $^{2}$

Pada pemberdayaan pertama itu PEKKA miskin di Kecamatan MKS telah dapat memiliki kelompok-kelompok usaha dengan memproduksi berbagai kreasi asesoris. Hasil produksi kelompok tersebut sudah dapat menjual kepada khalayak dengan cara yang sangat terbatas dan sederhana, karena kelompok ini belum bisa menguasai pemasaran dan masih terbatas dalam melakukan bisnis usaha. Hal ini dilatar belakangi oleh mereka sebagai pemula dalam mengembangkan usaha, tidak dapat memasarkannya. Di samping itu, karena selama PEKKA lebih nyaman bekerja sebagai pekerja domestik dan tidak terbiasa pula dengan pemasaran, sehingga kondisi ini

\footnotetext{
1 "Website Resmi Kota Bukittinggi," accessed October 22, 2019, http://www.bukittinggikota.go.id/site.

2 Adrian Bartenputra, "Pengaruh Kesesuaian Kompensasi, Ketaatan Akuntansi Dan Asimetri Informasi Terhadap Kecenderungan Kecurangan Akuntansi (Studi Empiris Pada SKPD Kota Bukittinggi)," Jurnal Akuntansi 4, no. 2 (June 10, 2016).
}

mempengaruhi terhadap cara pemasaran barang-barang yang diproduksinya. Padahal PEKKA sudah memiliki semangat untuk berwirausaha untuk mengembangkan usaha dan produksi yang dimilikinya, tetapi untuk memasarkannya mereka terkendala.

Keterbatasan dan kendala-kendala itu, diprediksi bisa menyebabkan PEKKA gulung tikar dengan usaha-usaha yang dilakukannya, sehingga merendahkan minat dan upaya ekonomi yang dilakukannya selama ini. Oleh sebab itu, untuk menghindari hal yang demikian maka diperlukan pembinaan dan pemberdayaan untuk PEKKA sehingga usaha dan kegiatan ekonominya bisa dipasarkan. Pemasaran ini, membantu PEKKA dan keluarga untuk sejahtera. Jika usaha-usaha yang dilakukannya itu tidak lagi berjalan, jelas kondosi keluarga PEKKA tidak berubah dan tidak beralih kepada kehidupan yang lebih sejahtera. Padahal, PEKKA sudah mencoba untuk bangkit dengan cara membangun usaha dimana sebelumnya lebih dominan melaksanakan pekerjaan sebagai PRT.

Langkah awal yang dilakukan dalam pemberdayaan ini adalah melakukan pemetaan potensi yang dimiliki oleh PEKKA. Pemetaan potensi ini dilakukan untuk pemilihan PEKKA berdasarkan kelurahan di kecamatan MKS. Dari sembilan kelurahan yang ada di kecamatan MKS secara purposive terpilih tiga kelurahan yang dijadikan sasaran pemberdayaan PEKKA. Tiga kelurahan itu adalah, Garegeh, Koto Selayang dan Cimpago Guguk Bulek. Setelah dilakukan pemetaan beberapa potensi yang sudah dimiliki oleh PEKKA diantaranya adalah; PEKKA memiliki semangat yang kuat untuk mengubah perekonomian rumah tangganya kearah yang lebih baik; PEKKA pada umumnya pekerja yang tangguh dan pantang menyerah; PEKKA pada umumnya punya anak dan tangungjawab; PEKKA memiliki keterampilan tetapi tidak berkembang; PEKKA belum mempunyai kelompok usaha mikro sebagai wadah untuk 
melakukan aktifitas ekonomi; PEKKA memiliki minat untuk mengembangkan usaha berupa keterampinan; PEKKA sudah ada mempunyai usaha dengan memproduksi produk tersendiri. ${ }^{3}$

Namun, PEKKA yang sudah mempunyai usaha itu memiliki masalah dalam pemasaran usaha-usaha yang dilakukannya, hal ini dapat dilihat diantaranya adalah; Tidak berkembangnya usaha secara signifikan karena terkendala dari segi pemasaran; Usaha yang dilakukan belum mampu mengubah kondisi kesejahteraan keluarga kearah yang lebih baik; Kecilnya jumlah produksi usaha yang dihasilkan, karena kecilnya barang-barang atau jasa yang diusahakannya terjual di pasaran.

Berdasarkan masalah-masalah di atas, maka diyakini penyebab yang paling dominan dialami oleh PEKKA yang punya usaha adalah rendahnya pengetahuan dan adanya kendala dalam memasarkan usaha-usaha yang diprosuksinya. Oleh sebab itu masalah di dalam pemberdayaan ini adalah bagaimana bentuk pemberdayaan pemasaran yang paling tepat dilakukan untuk PEKKA yang sudah mempunyai usaha ini.

\section{Metode}

Langkah awal yang dilakukan dalam pemberdayaan ini adalah melakukan pemetaan potensi yang dimiliki oleh PEKKA. Pemetaan potensi ini, dilakukan untuk setelah dilakukan pemilihan PEKKA berdasarkan kelurahan di kecamatan MKS. Dari sembilan kelurahan yang ada di kecamatan MKS secara purposive terpilih tiga kelurahan yang dijadikan sasaran pemberdayaan PEKKA. Tiga kelurahan itu adalah, Garegeh, Koto Selayang dan Cimpago Guguk Bulek. ${ }^{4}$

3 Siska Sasmita, "Peran Perempuan Suku Minangkabau Yang Menjadi Kepala Keluarga (PEKKA) Bagi Penciptaan Ketahanan Pangan Rumah Tangga Di Kecamatan Padang Timur," Humanus 10, no. 1 (July 30, 2012): 82, https://doi.org/10.24036/jh.v10i1.489.
Pada masing-masing keluruahan itu, diikutsertakan sepuluh orang PEKKA miskin. Profil dari sepuluh PEKKA miskin yang dijadikan objek dampingan ini, pada umumnya adalah mengalami percerian atas berbagai alasan. Semua PEKKA ini memiliki tanggungan anak diantaranya orang tua. Anakanak menjadi tanggung jawabnya. Perempuan juga bertanggung jawab untuk membina kehidupan keluarganya agar dapat menjadi keluarga yang mandiri dan sejahtera.dalam hal ini perempuan yang berstatus janda harus mampu menghidupi kebutuhan anak-anaknya demi kesejahteraan dirinya dan anak-anaknya yang ada dalam keluarga.

Di antara penetapan peserta pemberdayaan kalangan PEKKA miskin dari kelurahan ini merupakan hasil dari rekomendasi daripada pihak Kelurahan yang bersangkutan. Untuk mengefektifkan dan untuk dapat mencapai sasaran dari pemberdayaan telah dilakukan pemetaan keterampilan yang telah dimiliki PEKKA. Disamping itu juga atas rekomendasi dari pihak Dinas Sosial Kota Bukittinggi, dengan datadata yang sudah dikumpulkan oleh pekerja sosial. Setelah terkumpul data-data tersebut, dilakukan survey lapangan. Mendatangi langsung Pekka-Pekka tersebut satu persatu untuk melihat situasi dan kondisinya.

Untuk memastikan kondisi PEKKA tersebut, di lakukan survey dan kerja lapangan dengan mendatangi masing-masing PEKKA, serta memastikan jenis usaha yang dilakukannya masih berlanjut atau tidak. Pada umumnya usaha-usaha mereka masih berlanjut dan masih menjadi tulang punggung keluarganya, kemudian dari pengakuannya mereka masing sangat membutuhkan bimbingan untuk memasarkan produksi-

${ }^{4}$ Hepi Hapsari Handayani and Agung Budi Cahyono, "Pemetaan Partisipatif Potensi Desa (Studi Kasus: Desa Selopatak, Kecamatan Trawas, Kabupaten Mojokerto," Geoid 10, no. 1 (August 1, 2014): 99, https://doi.org/10.12962/j24423998.v10i1.705. 
produksi yang dihasilkan, bahkan diantara mereka sudah mengembangkan produksi tidak hanya aksesoris seperti yang dilakukan pada pendampingan tahun pertama.

\section{Temuan dan Pembahasan}

Berdasarkan uraian masalah di atas kondisi dampingan yang diharapkan adalah PEKKA miskin mampu keluar dari jeritan kemiskinan melalui potensi yang mereka miliki yaitu berupa kelompok usaha mikro yang bias bersaing di pasaraan, sehingga PEKKA bisa memasarkan produksi mereka secara professional yang dapat menunjang keberhasilan dan kesejahteraan hidup mereka dan keluarga. Dampingan bisa bangkit membangun kehidupan yang layak dan sejahtera dengan potensi-potensi yang dimiliki. Supaya potensi-potensi itu tumbuh dan berkembang, maka PEKKA miskin diberi dampingan untuk memotivasi usaha melalui pembinaan pemasaran.

Ada beberapa pengetahuan yang diperoleh oleh dampingan utuk melakukan pemasaran. Usaha produktif artinya yang bisa dipasarkan dan diminati oleh masyarakat. Menurut Swasta (1996) ada beberapa hal yang perlu diketahui oleh PEKKA dalam pemasaran.

\section{Orientasi Konsumen}

PEKKA harus mengatetahui orientasi dari konsumen tersebut, dengan cara:

1. Menentukan kebutuhan pokok dari pembeli yang akan dilayani dan dipenuhi.

2. Memilih kelompok pembeli tertentu sebagai sasaran dalam penjualan.

3. Menentukan produk dan program pemasarannya.

4. Mengadakan penelitian pada konsumen untuk mengukur, menilai dan menafsirkan keinginan, sikap serta tingkah laku mereka.

5. Menentukan dan melaksanakan strategi yang paling baik, apakah menitikberatkan pada mutu yang tinggi, harga yang murah atau model yang menarik.

\section{$\underline{\text { Koordinasi dan Integrasi }}$}

PEKKA harus membuat jaringanjaringan dengan yang lainnya, misalnya jaringan dengan pihak penyewa pelaminan jika ingin memasarkan asesorisnya, sebab masyarakat sekarang dalam melakukan kenduri memakai adanya asesoris, dan seterunsya. Perlu dilakukan networking dengan berbagai pihak, sehingga bisa menguasai pasar.

\section{Mendapatkan Laba Melalui Pemuasan Konsumen}

Memikirkan laba dengan cara salah satunya mempertahankan kualitas-kualitas barang yang dihasilkan, jangan kecewakan konseumen, karena kepercayaan konsumen bisa luntur diakibatkan rendahnya kualitas itu. Atau oleh pelayanan yang tidak jujur. Kondisi dampingan yang diharapkan memiliki kemandirian dalam melakukan usaha dan mampu memasarkan secara baik produksi yang dihasilkannya, sehingga dengan demikian PEKKA dapat mendapatkan kesejahteran bersama keluarganya. Untuk mencapai kondisi dampingan yang diharapkan maka, diperlukan beberapa strategi yang dapat mendukung, di antaranya adalah:

1. Memberikan pengetahuan dan motivasi usaha berbasis pasar. Mengingat PEKKA sudah memiliki usaha mikro berkelompok tetapi tidak memiliki pengetahuan untuk memasarkan usaha secara modern dan profesional maka harus memberikan pengetahuan tentang pemasaran dan motivasi dalam menjalan usaha.

2. Memberikan pelatihan dan dampingan pemasaran produk. Setelah mengetahui dan mendapatkan motivasi usaha selanjutnya adalah melakukan pendampingan dalam pemasaran produk yang dihasilkan, supaya produk yang dihasilkan dapat bersaing dan diterima dipasaran secara luas.

3. Membangun networking. Mendampingi PEKKA membangun networking dengan pihak-pihak terkait, minimal kelompok usaha PEKKA mendapatkan bapak angkat untuk membina pasaran dan permodalan 
guna kelanjutan dan kemajuan usaha PEKKA. Di samping itu mengupayakan pendekatan kepada pemerintah daerah supaya prouksi PEKKA bisa dipasarkan di sebuah geleri yang dapat dikunjungi oleh wisatawan.

Setelah dilakukan pendampingan dengan pemberian pengetahuan itu, maka dilakukan penyebaran angket kepada PEKKA untuk mendapatkan gambaran tiga hal dalam pemasaran itu, seperti orientasi, integritas dan keuntungan itu. Dari hasil angket diketahui bahwa PEKKA yang di dampingi sangat rendah cara orentasi dan integritas serta pemeliharan kualitasnya. Oleh sebab itu, pendampingan pemasaran memang sangat diperlukan oleh PEKKA dalam rangka memajukan usaha yang dilakukannya.

\section{Pendampingan Individual}

Setelah dilakukan pendampaingan berkelompok dengan pemberian pengetahuan tentang pemasaran, maka dilakukan pendampingan-pendampingan individual. Dimana pihak pendamping melakukan pengawasan-penagawasan terhadap usahausaha yang dilakukannya, mendiskusikan kepada pendampingan beberapa hal, diantaranya. Tentang kendala yang dihadapi, keuntungan yang diperoleh dan masalahmasalah yang perlu diatasi.

Pendampingan individual ini, dimana pendamping mendatangi dampingan secara individual ke rumah masing-masing, setelah dilakukan dampingan individual ini ada beberapa kendala yang dihadapi oleh PEKKA, pertama PEKKA tidak dapat melakukan pekerjaan produksi secara berkesinambungan karena faktor pekerjaan tersebut dilakukan oleh PEKKA itu sendiri tidak ada yang membantu.

Pekerjaan serabutan juga masih ditangani oleh PEKKA, mana yang lebih menguntungkan itulah yang lebih diprioritaskannya, sehingga sering usaha-usaha produksi unggulannya tertinggal. Hal ini terjadi dipengaruhi oleh kebutuhan ekonomi yang mendesak, PEKKA memerlukan adanya pemasukan setiap hari untuk menafkahi keluarganya. Jadi PEKKA selalu memprioritaskan pekerjaan yang lebih menggiurkan. Pada umumnya pekka melakukan hal yang seperti itu.

Seperti yang dilakukan oleh dampingan ini, keahlian utamanya adalah menyulam dan di kelompok usaha bersama melakukan usaha penjualan beras. Namun untuk kepentingan kehidupan keluarga, usaha sulaman atau border terpaksa dia tinggal untuk mengejar orderan yang lebih besar. Jadi ada kendala didalam hal ini, dimana dampingan tidak bekerja sepenuh waktu untuk produksi unggulannya sebagai penyulam, tetapi juga berserabautan. Menyulam dilakukan ketika waktu luang, oleh sebab itu pendampingan yang dilakukannya adalah momotivasi untuk memperhatikan orientasinya sebagai penyulam dan tetap mempertahankan networking yang sudah dilakukannya dengan pihak-pihak yang sudah dibangunnya jangan mengecewakan orangorang yang sudah menjadi bahagian dari pemasaran sulaman yang dilakukannya. Begitu pula yang dialami oleh kelompok usaha asesoris melakukan, juga melakukan pekerjaan diluar membuat dan memasarkan asesoris tersebut. Mendahulukan pekerjaan yang lebih dahulu menghasilkan uang. Tidak terfokus pada usaha-usaha produksi yang sudah dilakukannya. Kadang-kadang menjadikan usaha-usaha itu sebagai kegiatan sampingan bagi mereka.

Hal itu sangat wajar dilakukan oleh PEKKA karena mereka secara cepat juga ingin mendapatkan upah atau uang untuk menghidupkan keluarganya pada hari itu juga, atau untuk kebutuhan sekolah anak-anaknya atau untuk biaya rumah tangga. Ada beberapa upaya yang dilakukan kepada dampingan.

\section{Komunikasi Usaha}

Komunikasi usaha adalah adalah kegiatan pertukaran informasi atau gagasan yang dilakukan antara pendamping dengan 
dampingan. Tujuan untuk membangun dan mengembangkan usaha yang sudah dilakukan. Oleh karena itu komunikasi yang baik dan efektif sangat diperlukan adanya untuk menunjang keberhasilan atas keberlanjutan dan keuntungan ekonomis dari usaha yang dilakukan. Ada beberapa fungsi dari komunikasi usaha ini, yaitu:

1. Fungsi Informatif; Fungsi ini diperlukan dalam mewujudkan kelancaran aktiftas usaha.

2. Fungsi Regulatory. Komunikasi usaha membuat komunikasi dengan networking.

3. Fungsi Persuasive. Komunikasi usaha untuk mengubah atau mepengaruhi kepercayaan, sikap, dan perilaku seseorang sehingga bertindak sesuai dengan apa yang diharapkan.

4. Fungsi Integrative. Fungsi integratif adalah untuk menciptakan kenyamanan dalam melakukan kegiatan dalam menjalani usaha.

\section{Motivasi Untuk Berusaba}

Membicarakan terkait dengan selalu berfikiran positif dan tidak larut dengan kegagalan, kemudian menjadikan setiap yang terjadi adalah pembelajaran dan membangun semangat baru, sehingga tidak hidup selalu mengeluh dan berkeluh tetapi tetap dijalani dengan semangat dan menyenangi pekerjaan yang dilakukan. Untuk membantu menjelaskan tentang motivasi ini pendamping mengadobsi cara yang dikembangkan dalam komunitas pengembangan usaha.

\section{Membantu Informasi Pemasaran}

Membantu informasi pemasaran adalah memberikan informasi-informasi pasar yang membutuhkannya, seperti jika ada yang wisuda maka diberikan kepada pembuat asesoris untuk menawarkan produksinya kepada kebutuhan wisuda sebuah kampus itu, sehingga asesoris tersebut bisa terjual dan dibeli oleh pihak wisudawan, untuk kepentingan asesorisnya. Atau kepada pihak yang akan kenduri yang ingin memesan asesoris maka dikomunikasikan kepada pihak-pihak PEKKA yang membuat asesoris itu.

\section{Pendampingan Kelompok Sesuai Dengan Usaha}

Di samping dilakukan pendampingan individual juga dilakukan pendampinagn kelompok, yang dimasud dengan pendampingan kelompok adalah mendampingi PEKKA berdasarkan kelompok-kelompok usaha yang dilakukan. Ada tiga kelompok usaha besar, yakni melakukan usaha sulaman, asesoris-souvenir dan makan ringan. Kelompok-kelompok ini didampingi dengan tujuan untuk mengevaluasi dari pekerjaanusaha yang dilakukan oleh kelompok ini, dan sejauh mana capaian yang dihasilkannya daripada pendampingan tersebut.

Dari hasil pendampingan diketahui, bahwa dampingan masih saja mengeluh dalam menjalankan usahanya bukan diakibatkan oleh pasar yang terbatas tetapi disebab oleh modal yang dimiliki terlalu kecil, sehingga sulit untuk mengembangkan usahanya. Keterbatasan modal ini pula yang menyebabkan kadangkadang mereka berproduksi atau membuat usaha-usaha handalannya.

Misalnya dalam sulaman, mahalnya harga benang dan kain membuat terhentinya kegiatan tersebut, kadang-kadang hanya menunggu pesanan dan pemesan harus terlebih dahulu memberikan modal separuh, baru bisa melakukan kegiatan bordirannya. Alasan modal ini menjadi alasan klasik yang dikemuakan oleh semua PEKKA. Seperti diuraikan oleh kelompok sulaman, menyulam memubutuhkan modal yang banyak dan waktu lama, maka untuk itu diperlukan modal untuk produksi ini. Padahal keuntungan dalam menyulam itu lebih besar dibandingkan dengan usaha souvenir dan makanan ringan.

Dari tiga kelompok usaha, yang paling sering mengalami keterhentian pemasaran akibat tidak produksi adalah yang melakukan usaha sulaman-atau border, karena mereka membutuhkan modal besar. Maka menyulam itu dilakukan ketika ada permintaan dengan 
jaminan harus terlebih dahulu memberikan separuh dari harga jual. Walaupun makanan ringan dan asesoris itu selalu berproduksi namun bukan berarti tidak mengalami kendala akibat dari modal, misalnya pada waktu-waktu tertentu peluang pasar cukup besar tetapi modal untuk berproduksi terkendala, sehingga tetap tidak mendapatkan kesempatan dalam pasar tersebut, sebagaimana diakui oleh PEKKA asesoris, mengetahui pasaran pada waktu-waktu tertentu sangat membutuhkan tetapi akibat dari modal sehingga tidak bisa mengambil kesempatan pasar tersebut.

Solusi yang ditempuh adalah menegosiasikan PEKKA dengan pihak pengambil kepentingan, terutama dengan pihak pekerja sosial supaya mereka mendapatkan bantuan berupa modal usaha, namun karena tidak adanya bantuan individual harus dilakukan dengan berkelompok. Salah satunya mereka harus membentuk kelompok usaha bersama. Negosiasi ini bisa dilakukan dalam membantu usaha yang dilakukan oleh pelaku atau pembantu pelaku. Tujuannya adalah untuk mendapatkan kata sepakat yang mengandung kesamaan persepsi, saling pengertian, dan persetujuan. Untuk mendapatkan jalan keluar dari masalah yang dihadapi bersama. Untuk mendapatkan atau mencapai kondisi saling menguntungkan, yang dihadapi oleh PEKKA dalam menjalani usahanya.

Di samping melakukan negosiasi kepada pihak-pihak pekerja sosial, juga dilakukan negosiasi kepada dinas pemberdayaan perempuan Kota Bukittinggi, jika ada pembinaan dan pemberian bantuan modal maka diprioritaskan kepada kelompok PEKKA ini. Selain itu dilakukan negosiasi dengan pihak Pusat Studi Gender dan Anak IAIN Bukittinggi, terkait dengan pengutamaan pemberdayaan untuk kelompok-kelompok ini atau atas dasar riset kelompok ini bisa diusulkan sebagai penerima modal kepada pihak lain.
Konsep negosiasi ini diadopsi dari sistem networking pembedayaan terhadap peningkatan usaha yang dikembangkan oleh C. Putra sebagaimana dimuat di dalam Ciputraceo.net dengan menyebutkan, sebuah negosiasi dalam suatu usaha memiliki karkateristik yaitu, Proses negosiasi memiliki beberapa karakteristik penting untuk membentuk komponen-komponen dari sebuah negosiasi. Beberapa karakteristik dalam negosiasi antara lain adalah sebagai berikut :

1. Terdiri dari minimal dua orang atau lebih.

2. Adanya hal yang dinegosiasikan dan bukan tidak mungkin dapat timbul masalah.

3. Melibatkan barang atau jasa.

4. Melibatkan orang lain. Sebuah negosiasi kadang juga memerlukan bantuan pihak

5. Menggunakan bahasa lisan, ekspresi wajah, dan gerak tubuh.

6. Adanya kesepakatan kedua belah pihak. Negosiasi pada akhirnya akan mendapatkan sebuah keputusan

7. Dalam suatu kelompok untuk pengambilan keputusan kelompok.

Kepentingan negosiasi yang dilakukan di sini juga bertujuan dalam berbagai hal:

1. Agar dampingan mendapatkan bantuan modal

2. Agar mendapatkan pembinaan dan dampingan berkelanjutan

3. Agar dampingan bisa melakukan peningkatan dari usaha yang dilakukannya.

Jadi keberhasilan dari dampingan sangat ditentukan oleh pendampingan, negosiasi dan pembinaan berkelanjutan. Hal ini bisa berheti apabila pekka sudah mampu melakukan usaha untuk membangun kesejahteraanya.

\section{Pemberian Modul Bacaan Terkait}

Pada umumnya PEKKA yang menjadi dampingan adalah tamatan SLTA, maka diprediksi dalam menjalankan usaha sangat membutuhkan acuan secara otodidak, bisa mendapatkan inspirasi dari bahan-bahan bacaan. Maka dalam pendampingan ini, 
diberikan kepadanya bahan-bahan bacaan terkait dan bahan bacaan motivasi usaha. Bahan bacaan ini dikopikan sebanyak dampingan. Bahan bacaan ini, bisa digunakan sebagai:

1. Bahan pembelajaran

2. Sumber informasi

3. Sumber motivasi

4. Sumber inspirasi

5. Sumber Pembelajaran

Terbatasnya sumber bacaan selama ini dilami oleh PEKKA, juga menyebabkan PEKKA minim daya kreatif dan motivasi hal ini dapat dilihat dari jawaban yang diberikan ketika diberikan beberapa pertanyaan, tetang bagaimana cara mereka mengembangkan usaha, hanya mengadalkan informasi dari pada pihak-pihak yang melibatkannya, sangat terbatas sumber informasinya.

Di samping itu, tidak melakukan pencarian-pencarian kepada sumber informasi, pada hal saat sekarang bisa dilakukan dengan pencarian dengan google, tetapi mereka tidak terbiasa dan tidak ada yang mendampinginya sehingga alat komunikasi merek hanya betulbetul sebagai komunikasi dengan orang-orang yang diperlukan.

Modula atau bahan bacaan yang dimiliki oleh PEKKA bisa diharapkan untuk kemajuan:

1. Kelompok usaha mikro ini berkelanjutan dan mampu mengembangkan usaha

2. Kelompok usaha mikro dapat membangun ekonomi secara berkelompok

3. Kelompok memiliki susunan kepengurusan sehingga keberadaan kelompok lebih terkoordinasi

4. Kelompok terperhatikan oleh pihak-pihak yang terkait, seperti oleh lembaga pemberi modal, pemberdayaan dan seterusnya.

Jadi bahan bacaan yang dimiliki oleh Pekka itu diarapkan untuk meningkatkan sumber daya yang dimilikinya, minimal mampu membangun motivasi untuk mengembangkan usaha dan pemasaran.

\section{Kesimpulan}

Setelah selesai dilaksanakan maka perlu dilakukan evaluasi daripada program yang dilakukan, evaluasi untuk mengetahui tentang capaian-capaian yang sudah diperoleh dalam program. Pada umumnya dampingan telah mendapatkan pengetahuan tentang pemasaran, baik secara kelompok maupun secara individual. Bahkan pada saat FGD dampingan mendapatkan uraian dan penjelasan-penjelasan mulai dari pemasaran sampai pada untuk pengembangan usaha. Pengetahuan ini, diantara yang diperoleh adalah upaya-upaya yang dilakukan untuk berhasilnya suatu produk dengan mengembangkan motivasi, integritas dan perhitungan keuntungan. Indikator berhasil atau tidaknya suatu produksi dipasaran sangat ditentukan oleh keuntungan yang diperoleh.

Dampingan sudah termotivasi dalam menjalankan usahanya dengan adanya pengetahuan permasaran, hal ini terlihat dari kelompok aksesoris karena mereka lebih banyak mendapatkan pasaran dan modalnya tidak begitu besar. Namun pada kelompok border, pemasaran sangat tergantung pada pesanan. Dengan kondisi yang demikian, kelompok ini terpaksa kerja dengan serabutan dengan tawaran yang lainnya. Hanya memproduksi sulaman ketika ada pesanan dan pada pesanan itu mesti ada bayaran separuh daripada harga.

Maka untuk itu harus memasarkan kepada pihak-pihak yang mau memberikan modalnya terlebih dahulu, jika tidak ada pesanan kelompok ini terpaksa melakukan pekerjaan yang lain, sesuai dengan tawarantawaran yang ada, misalnya melakukan pembungkusan terhadap pakaian yang dilakukan oleh Pekka sulaman. Sedangkan pada kelompok asesoris kadang-kadang mereka terpaksa dimodivikasi dengan asesoris yang lain dengan cara membeli asesoris lain, kemudian menjualnya kepada yang lain dengan mengambil untung dari hasil penjualan itu 
sebagaimana dilakukan oleh Pekka kelompok aseseoris, ketika ada pesanan yang tidak terpenuhi kolaboratif usaha seperti itu dilakukannya.

\section{Daftar Kepustakaan}

Bartenputra, Adrian. "Pengaruh Kesesuaian Kompensasi, Ketaatan Akuntansi Dan Asimetri Informasi Terhadap Kecenderungan Kecurangan Akuntansi (Studi Empiris Pada SKPD Kota Bukittinggi)." Jurnal Akuntansi 4, no. 2 (June 10, 2016).

Handayani, Hepi Hapsari, and Agung Budi Cahyono. "Pemetaan Partisipatif Potensi Desa (Studi Kasus: Desa Selopatak, Kecamatan Trawas, Kabupaten Mojokerto." Geoid 10, no. 1 (August 1, 2014): 99. https://doi.org/10.12962/j24423998.v10 i1.705.

Sasmita, Siska. "Peran Perempuan Suku Minangkabau Yang Menjadi Kepala Keluarga (PEKKA) Bagi Penciptaan Ketahanan Pangan Rumah Tangga Di Kecamatan Padang Timur." Humanus 10, no. 1 (July 30, 2012): 82. https://doi.org/10.24036/jh.v10i1.489.

"Website Resmi Kota Bukittinggi." Accessed October 22, 2019.

http://www.bukittinggikota.go.id/site. 